\title{
Controlling the Risk of Bacillus in Food Using Berries
}

\author{
Elisaveta Sandulachi, Viorica Bulgaru*, Aliona Ghendov-Mosanu, Rodica Sturza* \\ Technical University of Moldova, Chisinau, Republic of Moldova (RM) \\ Email: ^rodica.sturza@chim.utm.md, *viorica.bulgaru@tpa.utm.md
}

How to cite this paper: Sandulachi, E., Bulgaru, V., Ghendov-Mosanu, A. and Sturza, R. (2021) Controlling the Risk of Bacillus in Food Using Berries. Food and Nutrition Sciences, 12, 557-577. https://doi.org/10.4236/fns.2021.126042

Received: May 24, 2021

Accepted: June 18, 2021

Published: June 21, 2021

Copyright (อ 2021 by author(s) and Scientific Research Publishing Inc. This work is licensed under the Creative Commons Attribution International License (CC BY 4.0).

http://creativecommons.org/licenses/by/4.0/ (c) (i) Open Access

\begin{abstract}
Introduction: Increasing the shelf life of foods without the addition of synthetic additives is a demand from both producers and consumers. Spore-forming bacteria are a problem in the food industry. To reduce their impact, it is necessary to use complex technologies, as well as ingredients with antibacterial or antibiotic properties. The aim of this study was to develop initial symbiotic combinations between lactic acid bacteria and berries to control food quality. The relevant ability of lactic acid bacteria in the presence of berry additives to inhibit the growth of Bacillus strains that degrade bakery products and dairy products was investigated. The antibacterial effect of berries on the growth of Bacillus mesentericus was studied. Methods: In this study was used inhibition zone test, also called Kirby-Bauer Test. The growth rate of bacteria was based on the measurement of the optical density at 600 $\mathrm{nm}$ (OD600). The method of Thompson et al. has been used to research the development of ropiness disease in wheat bread samples. Results: The diameter of the Bacillus pumilus growth inhibition zones under the berries action was as follows: aronia $-18.0 \pm 0.6 \mathrm{~mm}$; raspberry $-16.0 \pm 0.4 \mathrm{~mm}$; strawberry $-15.0 \pm 0.5 \mathrm{~mm}$. Lactic bacteria in the presence of berry additives showed a growth rate, measured by optical density (OD) at 600 from 0.073 to 0.651 (for aronia) from 0.071 to 0.609 (for raspberries), from 0.073 to 0.597 compared to the increase in environments without added fruit, which amounted to -0.050 to 0.410 . In the yogurt with added fruit, a synergism was formed with Streptococcus thermophilus, Lactobacillus delbrueckii subsp. Bulgaricus, Lactococcus lactis subsp Lactis biovar diacetilactis. The influence of fat-soluble extracts of sea buckthorn, rose-hip, and hawthorn fruits on the development of ropiness disease when storing wheat bread was investigated. The general Pearson coefficient (microbial count and $\mathrm{pH}$ ) for all fruit yogurt samples is 0.95066 . Conclusion: The combined use of lactic acid bacteria and berries (aronia, raspberry and strawberry) had a synergistic effect on the risk posed by Bacillus bacteria. $1 \%$ of fat-soluble extract from the vegetable matter
\end{abstract}


reduced the risk of ropiness disease in wheat bread. This is due to the cumulative effect of the berries chemical composition (antioxidants, organic acids, etc.), increased acidity, lowered $\mathrm{pH}$, and water activity of the food environment, below the development values of Bacillus.

\section{Keywords}

Risk of Bacillus, Berries, Lactic Acid Bacteria, Fermentation, Synergism, Bakery and Dairy Products

\section{Introduction}

Preventing food spoilage without the addition of chemical food additives, while increasing functional properties of wheat-based bakery products, is an increasing demand by the consumers and a challenge for the food industry [1]. Functional food according to the European Commission Concerted Action on Functional Food Science in Europe (FuFoSE) and the International Life Sciences Institute (ILSI) is a food that beneficially affects one or more target functions in the body beyond adequate nutritional effects in a way that is relevant to either an improved state of health and well-being and/or reduction of a disease risk [2]. A food can be made functionally by increasing the concentration, adding, or improving the bioavailability of a particular component [3]. Certainly, the last decade, when consumer preferences have shifted to mildly processed food, new opportunities arise for spore-forming spoilage and pathogenic organisms [4].

Bakery products have a very short shelf life. Their quality depends on the time interval between baking and consumption [5]. Spoilage of bakery products is mainly due to the growth of moulds, the main species belonging to the genera Aspergillus, Fusarium and Penicillium, as well as to the roping of the bread, caused by Bacillus sp., especially Bacillus subtilis and Bacillus licheniformis [6]. Statistics show that over the past decade, the number of small and medium-sized enterprises engaged in the production of bread and bakery products using non-traditional vegetable raw materials such as bran, seeds, grains, and legumes has increased. Such products are in demand among consumers, but the raw material is often a source of Bacillus bacteria, which requires the use of safe preservatives [7]. Considering the high microbiological contamination of raw materials (mainly flour) in the production of bread and bakery products, it is necessary to use complex technologies, as well as products with antimibacterial or antibiotic properties, to prevent the development of a ropiness disease and molding of bread [8].

Spore-forming bacteria can be a problem in the food industry, especially in the canning industry. Spores present in ingredients or present in the processing environment severely challenge the preservation process since their thermal resistance may be very high [9].

Cow's milk, which is one of the most complete foods [10], is at the same time 
a favorable breeding ground for microorganisms [11] [12]. The quality and stability of dairy products are largely determined by the initial bacterial contamination and the composition of the raw material microflora [11] [12] [13]. Optionally anaerobic sporulating microorganisms (Bacillus subtillis, Bacillus mesentericus (Bacillus pumilus), Bacillus megatherium, Bacillus mycoides and Bacillus sereus) have pronounced proteolytic properties, coagulate, and peptonize milk, cause hemolysis, release ammonia, hydrogen sulfide [14]. Research in recent years has established that these are significant microorganisms of damage to dairy products and food poisoning [15] [16]. Recent studies conducted by us have shown that the risk control posed by bacteria of genus Bacillus could be achieved by using berries in food manufacturing recipes. Fruits, berries medicinal plants have bactericidal and bacteriostatic properties [17]-[23]. Therofere, Pashenko et al. [24] developed a technology for producing rowan leaven, which included rowan powder, beet sugar molasses and kefir fungus. Leaven is a water-molasses extract fermented with kefir fungus. The symbiosis of lactic acid bacteria and kefir yeast cells has fungicidal and bactericidal activity due to the high content of sorbic acid, tannins, phytoncides and flavonoids.

To ensure microbiological quality and consumer safety, strict controls and hygienic conditions are observed by the dairy industry, as recommended by guidelines of good dairy farming [25] [26] and hygienic conditions at dairy plants [27].

The control of environmental parameters (temperature, $\mathrm{pH}$, water activity, salinity, atmosphere, presence of additives) can help the control of Bacillus cereus proliferation in foods. The ability to produce spores makes Bacillus cereus capable to escape processing conditions carried out by the food industries to preserve products and to eliminate or reduce the bacterial number in the final product [28]. Heat treatments commonly used by the food industry require longer treatments to efficiently eliminate Bacillus cereus spores [29].

The objective of the study was to evaluate the antimicrobial effect of different berries on the development of Bacillus bacteria in bakery and dairy products. Also, it was evaluated the combined effects of pasteurization intensity (no heat treatment and $10 \mathrm{~min}$ at $70^{\circ} \mathrm{C}, 80^{\circ} \mathrm{C}$ and $\left.90^{\circ} \mathrm{C}\right)$, water activity $\left(\mathrm{a}_{\mathrm{w}}\right)(0.960-$ $0.990), \mathrm{pH}(5.5-7.0)$ and storage temperature $\left(7^{\circ} \mathrm{C}\right.$ and $\left.10^{\circ} \mathrm{C}\right)$ on the survival and outgrowth of psychrotolerant spores of Bacillus cereus FF119b and Bacillus pumilus FF128a [30].

\section{General Characteristics of Genus Bacillus}

The ubiquitous soil bacterium Bacillus cereus presents major challenges to food safety. It is responsible for two types of food poisoning, the emetic form due to food intoxication and the diarrheal form emerging from food infections with enteropathogenic strains, also known as toxico-infections [31]. Bacillus cereus is a Gram positive, spore-forming and facultative anaerobic rod, which is ubiquitously found in dust, ground, on plant surfaces or in the rhizosphere [32] [33] 
[34]. Bacteria of the genus Bacillus are aerobic or facultative anaerobic, Gram positive, mostly catalase-positive and sporogenous. Cells are rod-shaped with rounded or straight ends. In later stages of growth some species may have Gram-variable character. Bacillus cells occur singly, in pairs, or in shorter chains. The width and the length of cells were in the range of $0.4-1.8 \mu \mathrm{m}$ and $0.9-10 \mu \mathrm{m}$ [35].

The factors that influence microbes' growth included physical and chemical requirements [36]. The physical requirements for growth fall into three groups namely temperature, $\mathrm{pH}$ and osmotic pressure [37]. The temperature optimum of Bacillus cereus is in the range of $28^{\circ} \mathrm{C}-35^{\circ} \mathrm{C}$. The growth occurs over a wide $\mathrm{pH}$ range of 4.4 - 9.3 [38]. The growth of genus Bacillus bacteria is inhibited especially by acid $\mathrm{pH}$. However, some studies showed that Bacillus cereus could be able to survive and to grow for a certain period of time even at $\mathrm{pH} 4.2-4.8$ [39]. Bacillus subtilis, aerobic rods which occur individually, in pairs, or exceptionally in chains. The cell size is in range of $(0.7-0.8) \times(2.0-3.0) \mu \mathrm{m}$. Endospores have an oval to cylindrical shape, they are located centrally, paracentrally or subterminally and do not increase the cell diameter. The temperature optimum of $\mathrm{Ba}$ cillus subtilis is in the range of $28^{\circ} \mathrm{C}-30^{\circ} \mathrm{C}$. The growth occurs over a $\mathrm{pH}$ range of $5.5-8.5$ [35].

Some reports implied growth of Bacillus thuringiensis in soil by suggesting germination in soil at a $\mathrm{pH}$ above 6.0 and temperatures above $15.5^{\circ} \mathrm{C}$ [40]. Table 1 includes the results of the study conducted by Isnawati and Trimulyono [37].

Table 2 includes the characteristics of Bacillus species based on studies by [35] [39] [41].

\section{Materials and Methods}

\subsection{Bacillus mesentericus (Bacillus pumilus)}

For research Bacillus pumilus was grown in laboratory conditions, the isolation medium served the potato. Appropriate solutions were prepared from pure culture.

\subsection{Preparation of Fruits Pulp}

Freshly ripened berries (aronia, raspberry and strawberry) were gently washed under water and cleaned with an aseptic knife. The fruits were processed by scalding at $95^{\circ} \mathrm{C}$ for $5 \mathrm{~min}$, packed in glass jars and stored at $4.0^{\circ} \mathrm{C} \pm 1.0^{\circ} \mathrm{C}$.

Table 1. The turbid score of indigenous bacterials that was grown at $\mathrm{pH} 6$ and various temperatures.

\begin{tabular}{lcccccc}
\hline & \multirow{2}{*}{$\begin{array}{c}\text { Species of } \\
\text { No. }\end{array}$} & indigenous bacterials & $\mathrm{pH}$ value & Turbid & \multicolumn{3}{c}{ Temperature, ${ }^{\circ} \mathrm{C}$} \\
\cline { 5 - 7 } & & score & 4 & 30 & 50 \\
\hline 1. & Bacillus subtilis & 6 & 0.343 & Grow & Grow & Grow \\
2. & Bacillus pumilus & 6 & 0.629 & Grow & Grow & None \\
3. & Bacillus cereus & 6 & 0.288 & None & Grow & Grow \\
\hline
\end{tabular}




\subsection{Preparation of Fat-Soluble Extracts of Sea Buckthorn, Rose-Hip, and Hawthorn Fruits}

Sea buckthorn, rosehip and hawthorn fruits were dried at $65^{\circ} \mathrm{C} \pm 1^{\circ} \mathrm{C}$ to a moisture content of $8.3 \% \pm 0.2 \%$ and ground to a powder. The fat-soluble extracts were obtained from powders of sea buckthorn, rose-hip, hawthorn and refined deodorized sunflower oil in a ratio of 1:12,1:14,1:20, respectively, at temperature of $45^{\circ} \mathrm{C}$ in time of $90 \mathrm{~min}$, under mechanical agitation $60 \mathrm{rpm}$, in limited conditions of light penetration. The fat-soluble extracts were filtered and stored at $4^{\circ} \mathrm{C} \pm 1^{\circ} \mathrm{C}$.

\subsection{Yogurt Assortment}

For the yogurt manufacture the Lyofast YAB 205 starter culture was used for inoculation, which contain Streptococcus thermophilus, Lactobacillus delbrueckii subsp. Bulgaricus, Lactococcus lactis subsp Lactis biovar diacetilactis, sucrose and maltodextrin. The yogurt assortment obtained in laboratory conditins is presented in Table 3.

\subsection{Bread Making}

Samples of wheat bread were made using $1 \%$ and $2 \%$ fat-soluble extracts of sea buckthorn, rose-hip, and hawthorn fruits. The control sample was prepared

Table 2. The characteristics of Bacillus species.

\begin{tabular}{cccc}
\hline The characteristics & Bacillus cereus & Bacillus pumilus & Bacillus subtilis \\
\hline Anaerobic growth & + & - & - \\
Voges-Proskauer test & + & - & + \\
Glucose utilization & + & - & + /- \\
Lactose utilization & - & - & $+/-$ \\
Maltose utilization & + & + & $+/-$ \\
Arabinose utilization & - & + & + \\
Casein hydrolysis & + & - & + \\
Nitrate reduction & + & $+/-$ & $+/-$ \\
Growth at $50^{\circ} \mathrm{C}$ & - & - & - \\
Growth at $60^{\circ} \mathrm{C}$ & - & + & + \\
Growth in $7 \% \mathrm{NaCl}$ & $+/-$ & + & $+/-$
\end{tabular}

Table 3. Notify the probe.

\begin{tabular}{cc}
\hline Sample code & Sample description \\
\hline P1 & $50 \%$ goat's milk $+50 \%$ cow's milk, control sample \\
P2 & $45 \%$ goat's milk $+45 \%$ cow's milk $+10 \%$ aronia \\
P3 & $45 \%$ goat's milk $+45 \%$ cow's milk $+10 \%$ raspberries \\
P4 & $45 \%$ goat's milk $+45 \%$ cow's milk $+10 \%$ strawberry \\
\hline
\end{tabular}


without adding any fat-soluble extracts of vegetal material. The wheat bread samples were baked from dough prepared by direct method with the addition of sourdough (control sample) in an amount of $10 \%$.

\subsection{Media}

MRS-broth (medium of Man, Rogosa, Sharpe) (Scharlau); MRS-agar. Composition $\left(\mathrm{g} / \mathrm{dm}^{3}\right)$ : MRS-broth (Scharlau), agar, 20; MRSc $=$ MRS-broth $+10 \%$ aronia; MRSr $=$ MRS-broth $+10 \%$ raspberry; MRSs $=$ MRS-broth $+10 \%$ strawberry.

The studied strains of microorganisms were cultured in a liquid medium (MRS-broth) and on an agar medium (MRS-agar) at $37^{\circ} \mathrm{C}$ to examine the effect of berries and lactic acid bacteria on growth. The agar diffusion method was used to determine the antimicrobial activity of three prepared fruit supplements.

Nutrient broth Mueller Hinton broth (MHB), use in diffusion method for determining the antimicrobiological properties of berries.

\subsection{The Diffusion Method in Nutrient Broth Mueller Hinton Broth (MHB)}

In this study we used inhibition zone test, also called Kirby-Bauer Test. It is a qualitative method used to measure and compare the inhibitory activity levels of the tested substances (berries puree) [42].

\subsection{Growth Rate of Bacteria}

The methodology for this experiment was based on the work of Lambert et al. The most common way to assess microbial growth in solution is the measurement of the optical density at $600 \mathrm{~nm}\left(\mathrm{OD}_{600}\right)$. The method was based on absorbance detection mode and basically determines which portion of light passes through a sample, more specifically through a suspension of microorganisms [43].

\subsection{The Study of Ropiness Disease Development in Wheat Bread Samples}

The method of Thompson et al. [44] has been used to research the development of ropiness disease in wheat bread samples.

\subsection{Statistical Analysis}

The variance analysis of the results was carried out by least square method with application of Student test and Microsoft Office Excel program version 2010. The differences were considered statistically significant if probability was greater than $95 \%$ ( $p$-value $<0.05$ ). All assays were performed in triplicate. The experimental results were expressed as average \pm SD.

\section{Results and Discussions}

\subsection{Infection Incidence of Products with Bacillus}

Bacillus cereus is an endospore-forming, Gram-positive bacterium able to cause 
foodborne diseases. Bacillus cereus is also a food poisoning bacterium that can occasionally be an opportunistic human pathogen [45]. The data presented by Branda et al. [46] support the older school of thought, namely that Bacillus cereus is a saprophytic bacterium that is able to grow in the soil and, in addition, is adapted to translocate through the soil. Members of the aerobic spore-forming genus Bacillus are commonly isolated from many types of soil at a range of depths and altitudes, and under various climatic conditions [33] [34] [47] [48]. Bacillus was reported to occur in soil as spores, germinating and becoming active only when readily decomposable organic matter was available [49]. Vegetative cells and especially spores can easily enter the food chain via crop plants. According to this, the range of foods in which Bacillus cereus is detected is broadly diversified [50].

Bacteria of Bacillus cereus and Bacillus pumilus were found in whole wheat flour. Spores of the genus Bacillus, which enter the human body, can cause significant dysfunction of the immune system, gastrointestinal tract, liver, respiratory system, and nervous system. Therefore, even if spore bacteria do not cause ropiness disease in bread, it is better not to have them in the finished product. They may be present in large fractions of whole grain breads. The source of infection may be the air in the bakery [7]. Ropiness disease is mainly due to natural microflora and in particular to Bacillus subtilis or Bacillus pumilus. In the process of baking wheat bread, the bacteria are destroyed, but part of its spores can remain viable. The specific feature of ropiness disease is that its manifestation is most often visible to the user during the summer months when temperatures are noticeably higher, which is a prerequisite for activating it.

It has been found that biological methods of microbial decontamination, namely the use of natural biological substances from leavens have wide technological potential not only to prevent the most dangerous types of bread spoilage, such as ropiness disease, but also as natural additives, improvers of bread quality with intensive methods of its production [8]. Neysens and De Vuyst [51] used a modeling approach to describe the kinetics and production of L471 amylovorin of Lactobacillus amylovorus DCE 471, given its application during the production of type II rye dough. Influence of temperature, $\mathrm{pH}$ and undissociated lactic acid concentration on inhibition of Lactobacillus sakei CTC 494 growth in MRS broth.

There are many benefits of the sourdough application in bread making: improvements in the volume of the bread and the structure of the crumb [52] [53], the flavour [54], the nutritional value [55] [56] and shelf life [57] [58] [59], due to the delay of the staling process and the prevention of mould and bacterial spoilage, against saprophytic microorganisms: Bacillus subtilis, Bacillus mesentericus, Aspergillus niger, Penicillium $s p$. and Rhizopus $s p$., but none of them inhibited the growth of bakery yeasts Saccharomyces cerevisiae [52] [60]. The addition of sourdough is the best technique to keep the bread from spoilage meeting consumer's demand for natural food without additives [61]. Sourdough is a mixture 
of flour (from wheat, rye, rice, etc.) and water, which is fermented by the action of lactic acid bacteria and yeasts [61]. These microorganisms usually come from flour, dough ingredients or the environment.

The objectives to be achieved by the use of sourdough are a significant increase in the shelf life and the nutritional value of bread and improvement of the organoleptic properties of bread. The increase in the retention time of the sourdough bread is due to the higher levels of acidity and the higher concentration of produced organic acids in comparison to the commercial bread produced by using only yeasts [2].

With the inclusion of starter cultures, the $\mathrm{pH}$ falls very quickly, so the whole manufacturing process is accelerated, which leads to economic benefits for the producer. The secondary effects of the acidification and the fermentation time acceleration include changes in the enzymes activity of the cereal substrates or the bacterial strains [6]. These positive effects are associated with the metabolic activity of the selected pure cultures, yeast and homo- and heterofermentative lactic acid bacteria in the composition of the sourdough, e.g. lactic acid fermentation, proteolysis, exopolysaccharide production and synthesis of volatile and antimicrobial compounds [52]. Bacillus cereus is an endospore-forming, Gram-positive bacterium able to cause foodborne diseases. Lactic acid bacteria (LAB) are known for their ability to synthesize organic acids and bacteriocins, but the potential of these compounds against Bacillus cereus has been scarcely documented in food models [45].

Various methods to prevent microbiological infection of bread have been developed: technological, chemical, physical, biological and combined [7] [8] [51] [62] [63]. The study by Black et al. [64], includes factors analysis influencing the germination rate of Bacillus subtilis spores by very high pressure. Ropiness disease is mainly due to natural microflora and in particular to Bacillus subtilis or Bacillus mesentericus. When grinding the grain, it is transferred to the resulting flour. In the process of baking wheat bread, the bacteria are destroyed, but part of its spores can remain viable. The specific feature of ropiness disease is that its manifestation is most often visible to the user during the summer months when temperatures are noticeably higher, which is a prerequisite for activating it [37].

Despite developments in the dairy industry, premature milk spoilage due to the contamination by Bacillus cereus continues to be a problem and causes considerable economic losses. Bacillus cereus is ubiquitously present in nature and can contaminate milk through a variety of means from the farm to the processing plant, during transport or distribution [28]. Bacillus cereus was isolated from 9\%, $35 \%, 14 \%$ and $48 \%$ of raw milk, pasteurized milk, Cheddar cheese and ice cream samples, respectively. Bacillus cereus was not recovered in yogurt. The level of contamination with Bacillus cereus did not exceed $100 / \mathrm{mL}$ in raw milk, 1000/mL in pasteurized milk, 200/g in Cheddar cheese and 3800/g in ice cream [65]. In spite of the frequency with which dairy farms are contaminated with Bacillus 
cereus, no outbreaks of food poisoning have occurred from consumption of milk and milk products, except for a few cases caused by cream and certain desserts. Bacillus cereus can multiply during cheese manufacturing [66], a point that warrants further investigation. Bacillus cereus may contaminate other foods, if milk or a milk product is one of their ingredients, and, if conditions are right, multiply rapidly and produce sufficient toxin to induce symptoms of food poisoning. The possible presence of toxigenic Bacillus cereus is another reason why dairy foods and other foods should be handled appropriately both during processing and in the home. Eleven strains of Bacillus cereus isolated from milk and meat products have been used to study growth and sporulation profiles in detail [50].

A recent example of a microorganism causing undesired growth in consumer milk is Bacillus sporothermodurans producing highly heat-resistant spores (HRS) which may survive ultra-high temperature (UHT) treatment or industrial sterilization [67]. Cortezzo et al. [68] in their studies showed that treatment with oxidizing agents affects the inner membrane of Bacillus subtilis spores and sensitizes the spores to subsequent stress. Treatment of spores with oxidizing agents has been suggested to cause damage to the spore's inner membrane, a membrane whose integrity is essential for spore viability.

\subsection{Results}

Microorganisms of genus Bacillus, which are incidental in food, but affecting their quality, are increasingly becoming the object of research. This study aimed to characterize the berries potential on reducing the Bacillus pumilus risk in fermented foods. In this study, a three-phase experimental descriptive method was applied on a laboratory scale. The first phase was the observation of the $B a-$ cillus pumilus bacterial growth curve and the influence of temperature on the microorganisms' growth rate (Figure $1 \&$ Figure 2). The second phase was the study of the berry additives influence on reducing the Bacillus pumilus risk infection (Table 4, Figure 3). The third phase was the berry additions influence on the ropiness disease development during the wheat bread storage and in the process of lactic acid fermentation (Table 5, Figure 4). The number of growing bacterial colonies was calculated using the total plaque counting method. The results showed that Bacillus subtilis had an optimal growth point at the eighth hour, achieving a total population of $6.1 \times 10^{13} \mathrm{CFU} / \mathrm{mL}$. The temperature of $37^{\circ} \mathrm{C}$ gave a growth rate higher than 4.6 compared to the temperature of $20^{\circ} \mathrm{C}$, which is 3.2 .

Results of studying the bacteriostatic properties of aronia, strawberry and raspberry in experiments with Bacillus pumilus are presented in Table 4.

A knowledge of the combined technologies with the appropriate concentrations of the "hurdles" in combination can contribute to the process design and control in order to assure the safety and quality of the products demanded by the consumer market. Activity of Lactobacillus cultures against bacteria and fungi is 
widely observed and frequently reported [69] [70]. Isolation of antimicrobial compounds from cell-free supernatant identified lactic acid, phenyllactic acid and the two cyclic dipeptides cyclo (1-Leu-1-Pro) and cyclo (1-Phe-1-Pro) are the major components responsible for this activity [71] [72]. These data are in accordance with results reported by Arena et al. [73], in which the production of antimicrobial compounds varied between $L p$. plantarum strains. In general, $L p$.

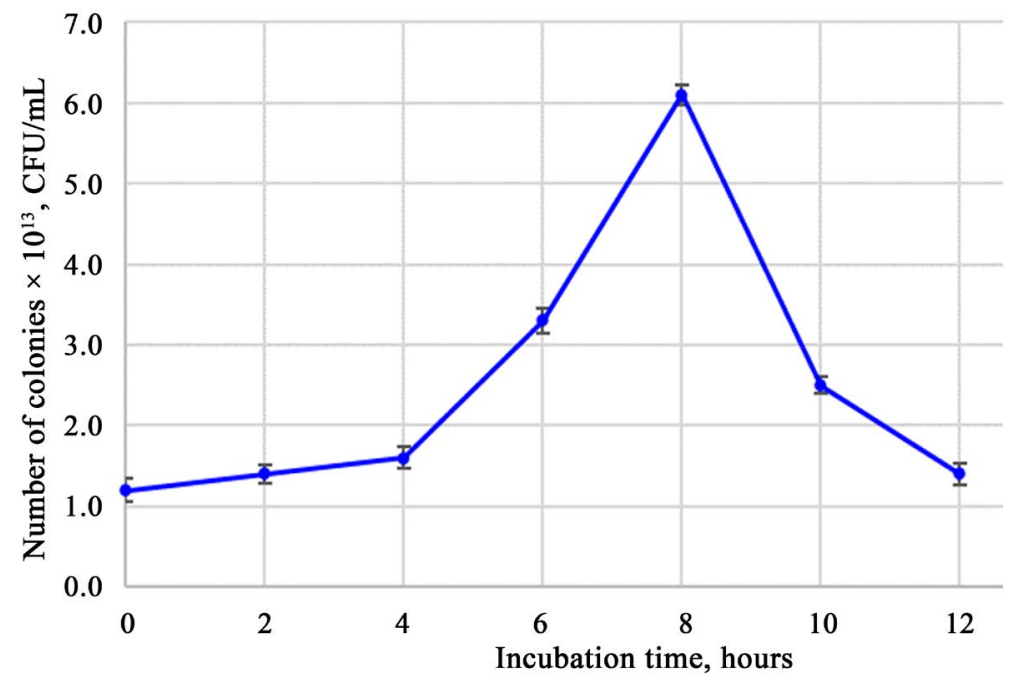

Figure 1. Growth curve studies of Bacillus pumilus (errors bars represent the standard deviation of three determinations).

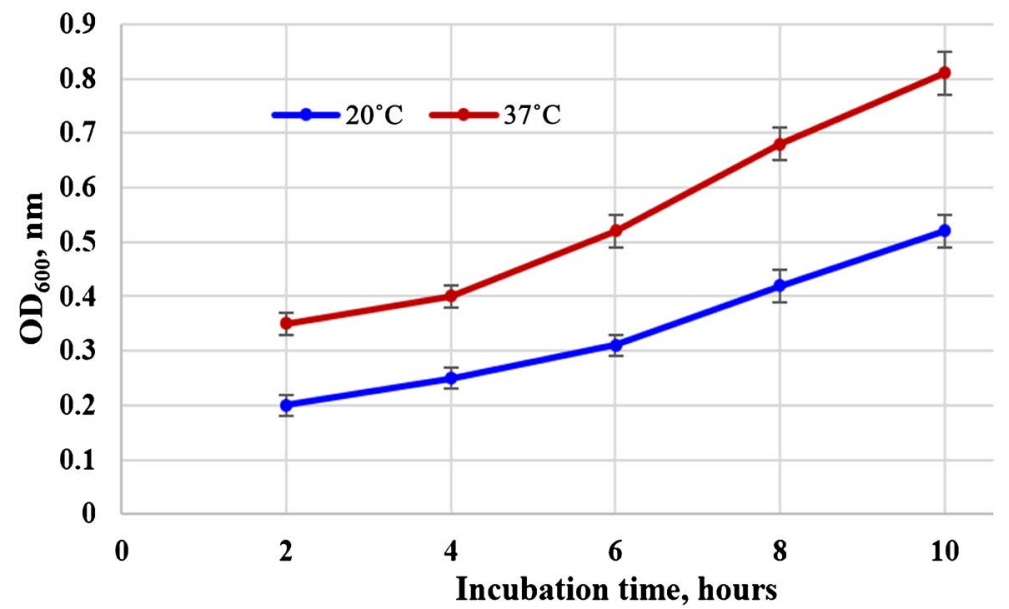

Figure 2. Modification of $\mathrm{OD}_{600}$ in samples tested for Bacillus pumilus incubated at different temperatures (errors bars represent the standard deviation of three determinations).

Table 4. Antimicrobial activity of berries.

\begin{tabular}{cccc}
\hline \multirow{2}{*}{ Microorganism strain } & \multicolumn{2}{c}{$\begin{array}{r}\text { The zones diameter of the microorganism growth } \\
\text { inhibition under the berries action, mm }\end{array}$} \\
\cline { 2 - 4 } & Aronia & Raspberry & Strawberry \\
\hline Bacillus pumilus & $18.0 \pm 0.6$ & $16.0 \pm 0.4$ & $15.0 \pm 0.5$ \\
\hline
\end{tabular}




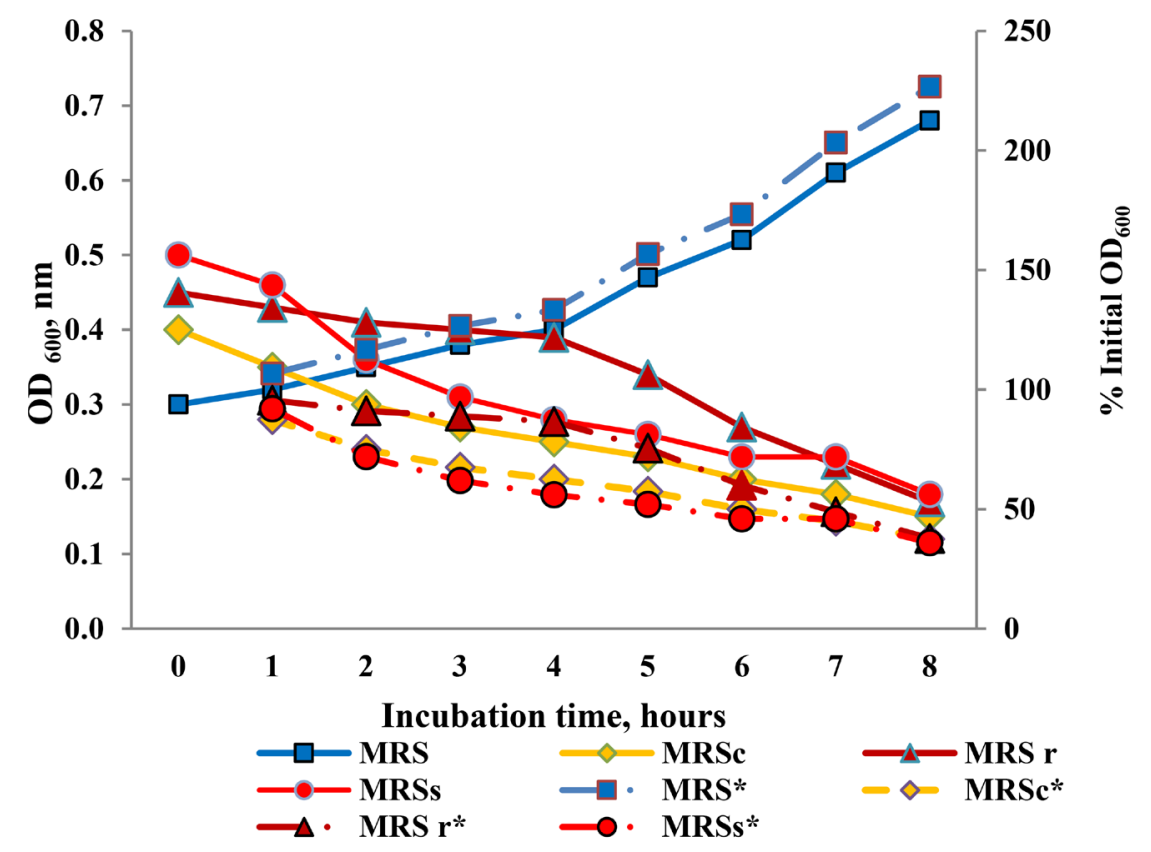

Figure 3. The impact of berries on Bacillus pumilus germination and out growth. Without ${ }^{*}$ refers to $\mathrm{OD}_{600}$ and with $*$ to $\%$ initial $\mathrm{OD}_{600}$. MRSc $=$ MRS-broth $+10 \%$ aronia; MRSr $=$ MRS-broth $+10 \%$ raspberry; MRSs $=$ MRS-broth $+10 \%$ strawberry.

plantarum S6.3 and S10.12 exhibited the highest inhibitory capability (diameter $23 \mathrm{~mm}$ ) against Bacillus cereus DSM31.

The ability of selected lactic acid bacteria to inhibit the growth of rope-forming Bacillus strains in laboratory experiments and in wheat bread was investigated. Growth of Bacillus subtilis and Bacillus licheniformis was inhibited by Lactobacillus plantarum VTT E-78076 and Pediococcus pentosaceus VTT E-90390 in an automated turbidometry assay and in test bakings [74].

The introduction of berries into the Bacillus pumilus growth medium reduced the germination rate of bacteria during 8 hours as follows: for aronias up to $37.50 \%$, for raspberries up to $37.78 \%$, and for strawberries up to $36.0 \%$. In the samples without the berries addition, the bacteria germination and growth occurred more during the whole tested period, Figure 3.

The objective of our previous research was to improve the quality of wheat bread and ensure its microbiological stability by using berry additives. The influence of berries (in the form of fat-soluble extracts) on stopping the wheat bread spread ropiness disease was investigated. The results are presented in Table 5.

The analysis of the results showed that $1 \%$ of fat-soluble extract from the vegetable matter reduced the ropiness disease risk in wheat bread. For bread samples with $1 \%$ of rose-hip, hawthorn and sea buckthorn fruits fat-soluble extracts the spoilage appeared after 96 hours and 120 hours respectively. The manifestation of ropiness disease signs is observed in wheat bread with low acidity. In order to prevent the bread disease with ropiness, lactic bacteria are introduced during the fermentation of wheat dough. Lactic acid bacteria Lactobacillus in the process of development from nutrient mixture carbon-containing components 
Table 5. Influence of rose-hip, sea buckthorn and hawthorn fruits fat-soluble extracts on the ropiness disease development when storing wheat bread products

\begin{tabular}{cccccccc}
\hline $\begin{array}{c}\text { Shelf life of wheat bread } \\
\text { samples until the } \\
\begin{array}{c}\text { appearance of ropiness } \\
\text { signs, hours }\end{array}\end{array}$ & Control & $\begin{array}{c}\text { Fat-soluble } \\
\text { extract } \\
\text { of rosehip fruits }\end{array}$ & \multicolumn{2}{c}{$\begin{array}{c}\text { Fat-soluble } \\
\text { extract of sea } \\
\text { buckthorn fruits }\end{array}$} & \multicolumn{2}{c}{$\begin{array}{c}\text { Fat-soluble } \\
\text { extract of } \\
\text { hawthorn fruits }\end{array}$} \\
\cline { 2 - 8 } 24 & - & - & - & - & - & - & - \\
48 & - & - & - & - & - & - & - \\
72 & + & - & - & - & - & - & - \\
96 & ++ & + & + & + & - & + & + \\
120 & +++ & +++ & +++ & +++ & + & +++ & +++ \\
144 & +++ & +++ & +++ & +++ & + & +++ & +++ \\
\hline
\end{tabular}

“-” no signs of microbial spoilage; “+” initial signs of ropiness development; “++" average intensity of ropiness development (stickiness, odor); “+++" intense of ropiness development (consolidation of unpleasant odor, stickiness).

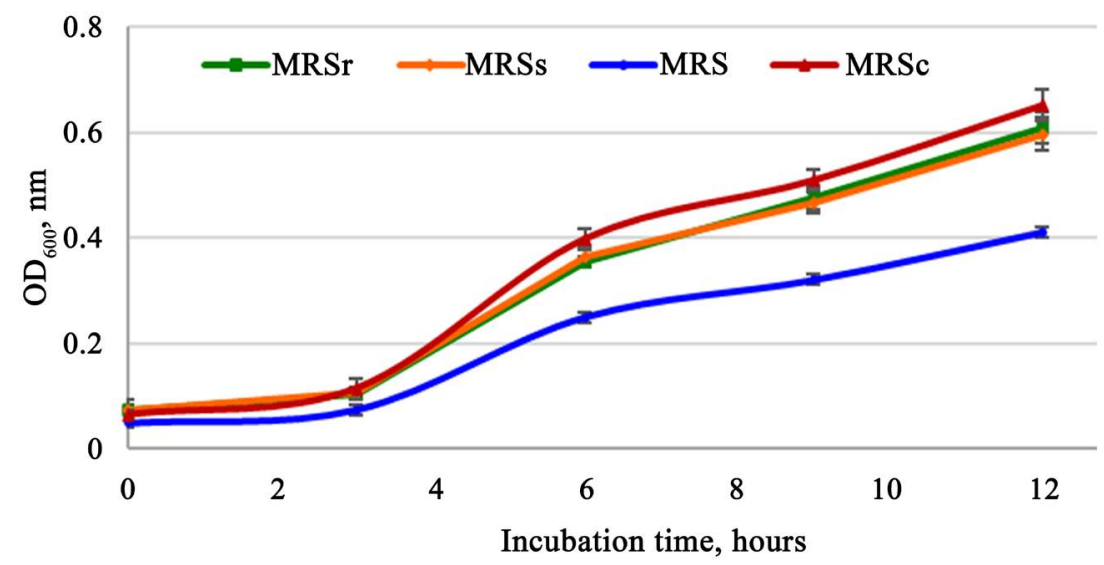

Figure 4. Growth rate of lactic acid bacteria in modified de Man, Rogosa, and Sharpe (mMRS) (errors bars represent the standard deviation of three determinations).

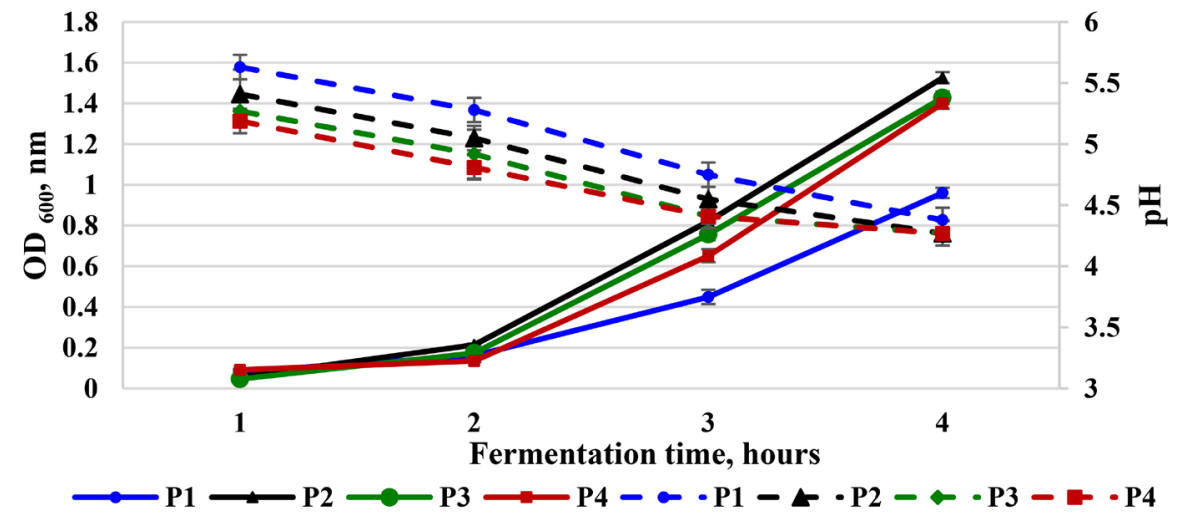

Figure 5. Change in $\mathrm{pH}$ and optical density at $600 \mathrm{~nm}\left(\mathrm{OD}_{600}\right)$ during fermentation of the tested yogurt samples (errors bars represent the standard deviation of three determinations). P1 - 50\% goat's milk $+50 \%$ cow's milk, control sample; $\mathrm{P} 2-45 \%$ goat's milk + $45 \%$ cow's milk $+10 \%$ aronia; $\mathrm{P} 3-45 \%$ goat's milk $+45 \%$ cow's milk $+10 \%$ raspberries; $\mathrm{P} 4-45 \%$ goat's milk $+45 \%$ cow's milk $+10 \%$ strawberry. 
form organic acids. The latter reduces active acidity and prevents the reproduction of unwanted microflora. Figure 4 shows the results of the berries influence on the lactic acid bacteria growth.

Growth rate of lactic acid bacteria in modified de Man, Rogosa, and Sharpe (MRSc, MRSr, MRSs) was significantly higher by the $12 \mathrm{~h}$ time point compared with traditional de Man, Rogosa, and Sharpe (MRS) broth. Lactic bacteria in the berry additives presence showed a growth rate, measured by OD at 600 from 0.073 to 0.651 (for aronia), from 0.071 to 0.609 (for raspberries), from 0.073 to 0.597 compared to the increase in environments without added fruit, which amounted to -0.050 to 0.410 (Figure 5).

The $\mathrm{pH}$ results obtained for the yogurt samples during fermentation varied in each sample, P2 (5.31 - 4.28), P3 (5.27 - 4.25), and P4 (5.19 - 4.27) relative to P1 (5.63 - 4.38). The optical density during fermentation was increased for all yogurt samples tested. The largest share of the increase in optical density was found in the berries yogurt samples. So in the fruit yogurt samples a synergism was created between the lactic bacteria and the chemical composition of the additions of raspberry, strawberry and aronia, which keeps under control the risk of Bacillus products infestation.

The pathogen Bacillus pumilus, which is associated with many foods including dairy products, was studied for its response to acid stress during the exponential phase. Lactic acid bacteria (LAB) are known for their ability to synthesize organic acids and bacteriocins, but the potential of these compounds against $\mathrm{Ba}$ cillus cereus has been scarcely documented in food models [44].

The results of this research showed that the combined use of lactic acid bacteria with the berries addition (aronia, raspberry and strawberry) had a synergistic effect, as expected, on the risk posed by Bacillus bacteria in food. Aronia was the most effective natural preservative, from the tested fruits, to prevent the damage of yogurt from cow's and goat's milk by Bacillus.

Knowledge of the combined technologies with the appropriate concentrations of "obstacles" in combination can contribute to the design and process control, to ensure the products safety and quality required by the consumer market [75] [76].

In studies conducted by [77] it was revealed that Bacillus subtilis were intolerant to acidic condition. During co-culture of Lactobacillus (five strains) or Lactococcus (two strains) with Bacillus cereus, organic acids and other potentially antimicrobial metabolites are produced. The strains that produced lactic acid fastest inhibited Bacillus cereus best [78].

The Pearson correlation [79] between the $\mathrm{pH}$ and the lactic acid bacteria growth in the classic yogurt samples fermentation process and with the berries addition was calculated. A high correlation was found a close relationship between variables, inversely proportional, because the values were obtained negative. The results are presented in Table 6.

The interdependence between $\mathrm{pH}$ and $\mathrm{OD}_{600}$ and the interdependence between 
Table 6. Pearson correlation between fermentation parameters in fruit yogurt.

\begin{tabular}{|c|c|c|c|c|}
\hline \multirow{2}{*}{ Indicator } & \multicolumn{4}{|c|}{ Pearson coefficient $(\mathrm{Pc})$} \\
\hline & P1 & P2 & P3 & P4 \\
\hline & -0.99672 & -0.99436 & -0.9782 & -0.96873 \\
\hline $\mathrm{Pc}=\mathrm{f}(\mathrm{pH} / \mathrm{CFU})$ & \multicolumn{4}{|c|}{$\begin{array}{l}\text { General Pearson coefficient for all fruit yogurt samples } \\
\qquad-0.95066\end{array}$} \\
\hline \multirow[b]{2}{*}{$\mathrm{Pc}=\mathrm{f}\left(\mathrm{CFU} / \mathrm{OD}_{600}\right)$} & 0.949961 & 0.96041 & 0.973807 & 0.948529 \\
\hline & \multicolumn{4}{|c|}{$\begin{array}{l}\text { General Pearson coefficient for all fruit yogurt samples } \\
\qquad 0.948124\end{array}$} \\
\hline & -0.94895 & -0.95951 & -0.92549 & -0.87325 \\
\hline $\mathrm{Pc}=\mathrm{f}\left(\mathrm{pH} / \mathrm{OD}_{600}\right)$ & \multicolumn{4}{|c|}{$\begin{array}{l}\text { General Pearson coefficient for all fruit yogurt samples } \\
\qquad-0.88087\end{array}$} \\
\hline
\end{tabular}

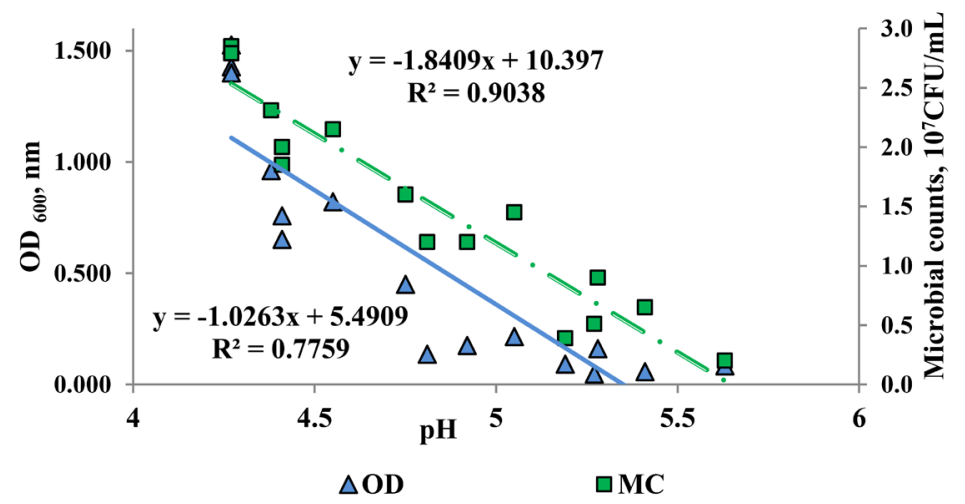

Figure 6. The interdependences between $\mathrm{pH} \mathrm{OD}_{600}$ and $\mathrm{pH}$, the lactic acid bacteria number in fruit yogurt.

$\mathrm{pH}$ and the lactic acid bacteria number in fruit yogurt are shown in Figure 6.

To control the Bacillus bacteria risk in food first is the in-depth knowledge about the survival and growth of Bacillus cereus, Bacillus pumilus and Bacillus subtilis in different food matrices, which depend mainly on $\mathrm{pH}$ and $\mathrm{a}_{\mathrm{w}}$ (water activity), processing and storage temperatures, oxygen availability and the microflora presence, but also in their production of bacteriocins, diacetyl, carbon dioxide, hydrogen peroxide, ethanol or other food additives [31] [80] [81] [82] [83].

Bacillus cereus was found to adapt to acid stress ( $\mathrm{pH} 4.6$ ) when pre-exposed to a non-lethal, inducing $\mathrm{pH}$ of 6.3 or to inducing concentrations of heat, ethanol, salt or hydrogen peroxide. Cells were found to maintain their internal $\mathrm{pH}$ at a higher level than the external acid $\mathrm{pH}$ and adapted cells had a higher internal $\mathrm{pH}$ than unadapted cells [84]. Optimum medium condition of Bacillus subtilis was reached at $37^{\circ} \mathrm{C}$ and $\mathrm{pH} 5.5$ [85]. Its ability to form spores makes the bacterium highly resistant towards environmental impacts such as drought, heat or radiation, as well as low $\mathrm{pH}$ values or chemical conservation [86].

\section{Conclusions}

The results of this research showed that the combined use of lactic acid bacteria 
and berries (aronia, raspberry and strawberry) of foods had a synergistic effect, as expected on the risk posed by Bacillus bacteria. Aronia was the most effective natural preservative, from the tested fruits, to prevent damage to yogurt from cow's and goat's milk by Bacillus. Knowledge of the combined technologies with the appropriate concentrations of "obstacles" in combination can contribute to the design and process control, to ensure the products safety and quality required by the consumer market.

Based on research, berries have been found to be an excellent means of controlling the food contamination with Bacillus risk. This is due to the cumulative effect of the berries chemical composition (content of antioxidants, organic acids, etc.), increased acidity, lowered $\mathrm{pH}$ and water activity of the food environment into which it was introduced, below the development values of Bacillus.

The antimicrobial berries properties were evaluated using the standard Kirby-Bauer disc diffusion method. It was found that berries (aronia, raspberry and strawberry) increase the growth rate of lactic acid bacteria forming a bactericidal synergism in fermented products (bread and yogurt). The results showed that $1 \%$ of fat-soluble extract from the vegetable matter reduced the ropiness disease risk in wheat bread.

From a microbiological point of view, in storage, all fruits formed an association to control the yogurt microbiological risk and stability, possess antimicrobial properties and fruit yogurt formed a synergism with Streptococcus thermophilus, Lactobacillus delbrueckii subsp. Bulgaricus, Lactococcus lactis subsp Lactis biovar diacetilactis. The general Pearson coefficient (microbial count and $\mathrm{pH}$ ) for all fruit yogurt samples is 0.95066 .

\section{Acknowledgements}

This work was supported by Moldova State project 20.80009.5107.09 "Improvement of food quality and safety by biotechnology and food engineering", running at Technical University of Moldova.

\section{Conflicts of Interest}

The authors declare no conflicts of interest regarding the publication of this paper.

\section{References}

[1] Şimşek, Ö., Çon, A.H. and Tulumoğlu, Ş. (2006) Isolating Lactic Starter Cultures with Antimicrobial Activity for Sourdough Processes. Food Control, 17, 263-270. https://doi.org/10.1016/j.foodcont.2004.10.011

[2] Rositsa, D., Svetla, I., Zapryan, D., et al. (2014) Production of Wheat Bread without Preservatives Using Sourdough Starters. Biotechnology \& Biotechnological Equipment, 28, 889-898. https://doi.org/10.1080/13102818.2014.965057

[3] Roberfroid, R. (2002) Functional Food Concept and Its Application to Prebiotics. Digestive and Liver Disease, 34, S105-S110. https://doi.org/10.1016/S1590-8658(02)80176-1 
[4] Abee, T., Groot, M.N., Tempelaars, M., Zwietering, M., et al. (2011) Germination and Outgrowth of Spores of Bacillus cereus Group Members: Diversity and Role of Germinant Receptors. Food Microbiology, 28, 199-208. https://doi.org/10.1016/j.fm.2010.03.015

[5] Ghendov-Mosanu, A., Cristea, E., Patras, A., Sturza, R., et al. (2020) Potential Application of Hippophae rhamnoides in Wheat Bread Production. Molecules, 25, 1272. https://doi.org/10.3390/molecules25061272

[6] Mentes, O., Ercan, R. and Akcelik, M. (2007) Inhibitor Activities of Two Lactobacillus Strains, Isolated from Sourdough, against Rope-Forming Bacillus Strains. Food Control, 18, 359-363. https://doi.org/10.1016/j.foodcont.2005.10.020

[7] Alashbayeva, L., Shansharova, D., Mynbayeva, A., et al. (2021) Development of Technology for Bakery Products. Food Science and Technology (Campinas), 1-7. https://doi.org/10.1590/fst.61120

[8] Rakhmonov, K.S., Atamuratova, T.I., Djuraeva, N.R., et al. (2020) Influence of Leavens of Spontaneous Fementation and Phytoadditives on the Provision of Microbiological Safety of Bread. Journal of Critical Reviews, 7, 850-860. https://doi.org/10.31838/jcr.07.05.177

[9] Oomes, S.J., van Zuijlen, A.C., Hehenkamp, J.O., Witsenboer, H., van der Vossen, J.M. and Brul, S. (2007) The Characterisation of Bacillus Spores Occurring in the Manufacturing of (Low Acid) Canned Products. International Journal of Food Microbiology, 120, 85-94. https://doi.org/10.1016/j.ijfoodmicro.2007.06.013

[10] Sandulachi, E. and Bulgaru, V. (2019). Factors Affecting Quality of Goat's Milk Yogurt. Advances in Social Sciences Research Journal, 6, 205-221.

https://doi.org/10.14738/assri.62.6129

[11] Nicolau, A. (2006) General Microbiology. Factors Influencing the Development of Microorganisms. Academica, Galati, 264. (In Romanian)

[12] Sandulachi, E., Rubțov, S., et al. (2017) Microbiological Control of Food. Ed. Tehnica, TUM, 128 p. (In Romanian)

[13] Dufrenne, J., Soentoro, P., Tatini, S., Day, T. and Notermans, S. (1994) Characteristics of Bacillus cereus Related to Safe Food Production. International Journal of Food Microbiology, 23, 99-109. https://doi.org/10.1016/0168-1605(94)90225-9

[14] Koroleva, N.S. (1975) Technical Microbiology of Whole Milk Products. Food Industry, M, 271. (In Russian)

[15] Borisova, G.V. (2001) Heat-Resistant Microorganisms Causing Defects in the Consistency and Organoleptic Properties of Dairy Products. Scientific Works of the All-Union State Agricultural Academy, 82-83. (In Russian)

[16] Vasiliev, D.A., Zolotukhin, S.N., Feoktistova, N.A., et al. (2013) Biosensor Detection of Bacteria of the Genus Bacillus in Milk and Dairy Products to Prevent Spoilage. Bulletin of the Ulyanovsk State Agricultural Academy, 4, 36-43. (In Russian)

[17] Nile, S.H. and Park, S.W. (2014). Edible Berries: Bioactive Components and Their Effect on Human Health. Journal of Nutrition, 30, 134-144. https://doi.org/10.1016/j.nut.2013.04.007

[18] Sandulachi, E. (2018) Redox Properties of Strawberries and Raspberries. Lambert Academic Publishing, SIA Omni Scriptum Publishing, Latvia, 109. (In Russian)

[19] Ghendov-Moșanu, A. (2018) Biologically Active Compounds of Horticultural Origin for Functional Foods. Ed. Tehnica-TUM, Chisinau, 236. (In Romanian)

[20] Sandulachi, E., Cojocari, D., Balan, G., Popescu, L., Ghendov-Moșanu, A. and Sturza, R. (2020) Antimicrobial Effects of Berries on Listeria monocytogenes. Journal of 
Food and Nutrition Sciences, 11, 873-886. https://doi.org/10.4236/fns.2020.119061

[21] Sturza, R., Sandulachi, E., Cojocari, D., Balan, G., Popescu, L. and Ghendov-Moșanu, A. (2019) Antimicrobial Properties of Berry Powders in Cream Cheese. Journal of Engineering Science, 3, 125-136.

[22] Khan, M.F., Tang, H., Lyles, J.T., Pineau, R., Mashwani, Z.R. and Quave, C.L. (2018) Antibacterial Properties of Medicinal Plants from Pakistan against Multidrug-Resistant ESKAPE Pathogens. Frontier in Pharmacology, 9, 815. https://doi.org/10.3389/fphar.2018.00815

[23] Munazir, M., Qureshi, R., Arshad, M. and Gulfraz, M. (2012) Antibacterial Activity of Root and Fruit Extracts of Leptadenia Pyrotechnica (Asclepiadaceae) from Pakistan. Pakistan Journal of Botany, 44, 1209-1213.

[24] Pashchenko, L.P., Kolomnikova, Ya.P., Ausheva, T.A. and Pashchenko, V.L. (2012) Biotechnological Aspects in Ensuring Microbiological Purity of Wheat Bread. Voronezh State University of Engineering Technologies Bulletin, 1, 87-89.

[25] D.G 158 from 07-03-2019, Regarding the Approval of the Quality Requirements for Milk and Dairy Products. Official Gazette No. 111-118 Art. 218, Annex 4. (In Romanian)

[26] IDF, F.A. (2011) Guide to Good Dairy Farming Practice. In Animal Production and Health Guidelines. International Dairy Federation and the Food and Agriculture Organization of the United Nations, Rome, 8.

[27] ISO 8086:2004 [IDF 121:2004] Dairy Plant-Hygiene Conditions-General Guidance on Inspection and Sampling Procedures.

[28] Vidic, J., Chaix, C., Manzano, M. and Heyndrickx, M. (2020) Food Sensing: Detection of Bacillus cereus Spores in Dairy Products. Biosensors, 10, 15.

https://doi.org/10.3390/bios10030015

[29] Dufrenne, J., Soentoro, P., Tatini, S., Day, T. and Notermans, S. (1994) Characteristics of Bacillus cereus Related to Safe Food Production. International Journal of Food Microbiology, 23, 99-109. https://doi.org/10.1016/0168-1605(94)90225-9

[30] Samapundo, S., Heyndrickx, M., Xhaferi, R., de Baenst, I. and Devlieghere, F. (2014) The Combined Effect of Pasteurization Intensity, Water Activity, $\mathrm{pH}$ and Incubation Temperature on the Survival and Outgrowth of Spores of Bacillus cereus and Bacillus pumilus in Artificial Media and Food Products. International Journal of Food Microbiology, 181, 10-18. https://doi.org/10.1016/j.ijfoodmicro.2014.04.018

[31] Jessberger, N., Dietrich, R., Granum, P. and Martlbauer, E. (2020) The Bacillus cereus Food Infection as Multifactorial Process. Toxins, 12, 701. https://doi.org/10.3390/toxins12110701

[32] Abee, T., Groot, M.N., Tempelaars, M., Zwietering, M., Moezelaar, R. and van der Voort, M. (2011) Germination and Outgrowth of Spores of Bacillus cereus Group Members: Diversity and Role of Germinant Receptors. Food Microbiology, 28, 199-208. https://doi.org/10.1016/j.fm.2010.03.015

[33] Jensen, G.B., Hansen, B.M., Eilenberg, J. and Mahillon, J. (2003) The Hidden Lifestyles of Bacillus cereus and Relatives. Environmental Microbiology, 5, 631-640. https://doi.org/10.1046/j.1462-2920.2003.00461.x

[34] Vilain, S., Luo, Y., Hildreth, M.B. and Brozel, V.S. (2006) Analysis of the Life Cycle of the Soil Saprophyte Bacillus cereus in Liquid Soil Extract and in Soil. Applied and Environmental Microbiology, 72, 4970-4977. https://doi.org/10.1128/AEM.03076-05

[35] Logan, N.A. and De Vos, P. (2015) Bacillus. In: Whitman, W.B., Ed., Bergey’s Ma- 
nual of Systematics of Archaea and Bacteria, John Wiley \& Sons, Inc., in Association with Bergey's Manual Trust, Hoboken, 1-164.

https://doi.org/10.1002/9781118960608.gbm00530

[36] Stanish, L.F., Hull, N.M., Robertson, C.E., Harris, J.K., Stevens, M.J., Spear, J.R. and Pace, N.R. (2016) Factors Influencing Bacterial Diversity and Community Composition in Municipal Drinking Waters in the Ohio River Basin, USA. PLoS ONE, 11, e0157966. https://doi.org/10.1371/journal.pone.0157966

[37] Isnawati and Trimulyono, G. (2018) Temperature Range and Degree of Acidity Growth of Isolate of Indigenous Bacteria on Fermented Feed "Fermege". Journal of Physics: Conference Series, 953, Article ID: 012209. https://doi.org/10.1088/1742-6596/953/1/012209

[38] Drobniewski, F.A. (1993) Bacillus cereus and Related Species. Clinical Microbiology Reviews, 6, 324-338. https://doi.org/10.1128/CMR.6.4.324

[39] Brožová, M., Kubizniaková, P. and Matoulková, D. (2018) Brewing Microbiology-Bacteria of the Genera Bacillus, Brevibacillus and Paenibacillus and Cultivation Methods for Their Detection-Part 1. Kvasny Prumysl, 64, 50-57. https://doi.org/10.18832/kp201813

[40] Saleh, S.M., Harris, R.F. and Allen, O.N. (1970) Fate of Bacillus thuringiensis in Soil: Effect of Soil pH and Organic Amendment. Canadian Journal of Microbiology, 16, 677-680. https://doi.org/10.1139/m70-116

[41] Priest, F.G. (2013) Bacillus. Colin R. Harwood. Springer Science \& Business Media, Berlin.

[42] Hudzicki, J. (2016) Kirby-Bauer Disk Diffusion Susceptibility Test Protocol. American Society for Microbiology, Washington DC, 23.

[43] Hall, B.G., Acar, H., Nandipati, A. and Barlow, M. (2014) Growth Rates Made Easy. Molecular Biology and Evolution, 31, 232-238.

https://doi.org/10.1093/molbev/mst187

[44] Thompson, J.M., Waites, W.M. and Dodd, C.E.R. (1998) Detection of Rope Spoilage in Bread Caused by Bacillus Species. Journal of Applied Microbiology, 85, 481-486. https://doi.org/10.1046/j.1365-2672.1998.853512.x

[45] Schoeni, J.L. and Wong, A.C. (2005) Bacillus cereus Food Poisoning and Its Toxins. Journal of Food Protection, 68, 636-648. https://doi.org/10.4315/0362-028X-68.3.636

[46] Branda, S.S., González-Pastor, J.E., Ben-Yehuda, S., Losick, R. and Kolter, R. (2001) Fruiting Body Formation in Bacillus subtilis. Proceedings of the National Academy of Sciences of the USA, 98, 11621-11626. https://doi.org/10.1073/pnas.191384198

[47] Garbeva, P., van Veen, J. and van Elsas, J. (2003) Predominant Bacillus spp. in Agricultural Soil under Different Management Regimes Detected via PCR-DGGE. Microbial Ecology, 45, 302-316. https://doi.org/10.1007/s00248-002-2034-8

[48] Kramer, J.M. and Gilbert, R.J. (1989) Bacillus cereus and Other Bacillus Species. In: Doyle, M.P., Ed., Foodborne Bacterial Pathogens, Marcel Dekker, Inc., New York, 21-50.

[49] Posada, R.H. (2017) Soil Microbiology in Agricultural Research in Relation to Ancient Knowledge. Agricultural Research \& Technology, 6, 43-45.

https://doi.org/10.19080/ARTOAJ.2017.06.555685

[50] Anderson, Borge, G.I., Skeie, M., Sorhaug, T., Langsrud, T. and Granum, P.E. (2001) Growth and Toxin Profiles of Bacillus cereus Isolated from Different Food Sources. International Journal of Food Microbiology, 69, 237-246. 
https://doi.org/10.1016/S0168-1605(01)00500-1

[51] Neysens, P. and De Vuyst, L. (2005) Kinetics and Modelling of Sourdough Lactic Acid Bacteria. Trends Food Science \& Technology, 16, 95-103.

https://doi.org/10.1016/j.tifs.2004.02.016

[52] Corsetti, A., Gobbetti, M., De Marco, B., Balestrieri, F., Paoletti, F., Russi, L. and Rossi, J. (2000) Combined Effect of Sourdough Lactic Acid Bacteria and Additives on Bread Firmness and Staling. Journal of Agricultural and Food Chemistry, 48, 3044-3051. https://doi.org/10.1021/jf990853e

[53] Crowley, P., Schober, T., Clarke, C. and Arendt, E. (2002) The Effect of Storage Time on Textural and Crumb Grain Characteristics of Sourdough Wheat Bread. European Food Research and Technology, 214, 489-496.

https://doi.org/10.1007/s00217-002-0500-7

[54] Thiele, C., Grassl, S. and Gänzle, M. (2004) Gluten Hydrolysis and Depolymerization during Sourdough Fermentation. Journal of Agricultural and Food Chemistry, 52, 1307-1314. https://doi.org/10.1021/jf034470z

[55] Ganzle, M. and Vogel, R. (2002) Contribution of Sourdough Lactobacilli, Yeast and Cereal Enzymes to the Generation of Amino Acids in Dough Relevant for Bread Flavour. Cereal Chemistry, 79, 45-51. https://doi.org/10.1094/CCHEM.2002.79.1.45

[56] Liljeberg, H., Lonner, C. and Bjorck, I. (1995) Sourdough Fermentation or Addition of Organic Acids or Corresponding Salts to Bread Improves Nutritional Properties of Starch in Healthy Humans. Journal of Nutrition, 125, 1503-1511.

[57] Corsetti, A., Gobbetti, M., Rossi, J. and Damiani, P. (1998) Antimould Activity of Sourdough Lactic Acid Bacteria: Identification of a Mixture of Organic Acids Produced by Lactobacillus sanfrancisco CB1. Applied Microbiology and Biotechnology, 50, 253-256. https://doi.org/10.1007/s002530051285

[58] Malthew, A., Renschler, A.W., Nnandi, A., et al. (2020) Using Nitrous Acid-Modified de Man, Rogosa, and Sharpe Medium to Selectively Isolate and Culture Lactic Acid Bacteria from Dairy Foods. Journal of Dairy Science, 103, 1215-1222. https://doi.org/10.3168/jds.2019-17041

[59] Marín, S., Abellana, M., Rubinat, M., Sanchis, V. and Ramos, A.J. (2003) Efficacy of Sorbates on the Control of the Growth of Eurotium Species in Bakery Products with near Neutral pH. International Journal of Food Microbiology, 87, 251-258. https://doi.org/10.1016/S0168-1605(03)00068-0

[60] Guynot, M.E., Ramos, A.J., Sanchis, V. and Marín S. (2005) Study of Benzoate, Propionate, and Sorbate Salts as Mould Spoilage Inhibitors on Intermediate Moisture Bakery Products of Low pH (4.5-5.5). International Journal of Food Microbiology, 101, 161-168. https://doi.org/10.1016/j.ijfoodmicro.2004.11.003

[61] Corsetti, A. and Settanni, L. (2007) Lactobacilli in Sourdough Fermentation. Food Research International, 40, 539-558. https://doi.org/10.1016/j.foodres.2006.11.001

[62] Guynot, M., Marin, S., Sanchis, V. and Ramos, A. (2005) An Attempt to Optimize Potassium Sorbate Use to Preserve Low pH (4.5-5.5) Intermediate Moisture Bakery Products by Modelling Eurotium spp., Aspergillus spp. and Penicillium corylophiIum Growth. International Journal of Food Microbiology, 101, 169-177. https://doi.org/10.1016/j.ijfoodmicro.2004.11.002

[63] Albiac, M.A., Di Cagno, R., Filannino, P., Cantatore, V. and Gobbetti, M. (2020) How Fructophilic Lactic Acid Bacteria May Reduce the FODMAPs Content in Wheat-Derived Baked Goods: A Proof of Concept. Microbial Cell Factories, 19, 182. https://doi.org/10.1186/s12934-020-01438-6 
[64] Zougagh, S., Belghiti, A., Rochd, T., Zerdani, I. and Mouslim, J. (2019) Medicinal and Aromatic Plants Used in Traditional Treatment of the Oral Pathology: The Ethnobotanical Survey in the Economic Capital Casablanca, Morocco (North Africa). Natural Product and Bioprospecting, 9, 35-48. https://doi.org/10.1007/s13659-018-0194-6

[65] Black, E.P., Wei, J., Atluri, S., Cortezzo, D.E., Koziol-Dube, K., Hoover, D.G. and Setlow, P. (2007) Analysis of Factors Influencing the Rate of Germination of Spores of Bacillus subtilis by Very High Pressure. Journal of Applied Microbiology, 102, 65-76. https://doi.org/10.1111/j.1365-2672.2006.03062.x

[66] Ahmed, A.H., Moustafa, K. and Marth, E.H. (1983) Incidence of Bacillus cereus in Milk and Some Milk Products. Journal of Food Protection, 46, 126-128. https://doi.org/10.4315/0362-028X-46.2.126

[67] Mikolajcik, E.M., Kearney, J.W. and Kristoffersen, T. (1973) Fate of Bacillus cereus in Cultured and Direct Acidified Skim Milk and Cheddar Cheese. Journal of Milk and Food Technology, 36, 317-320. https://doi.org/10.4315/0022-2747-36.6.317

[68] Cortezzo, D.E., Koziol-Dube, K., Setlow, B. and Setlow, P. (2004) Treatment with Oxidizing Agents Damages the Inner Membrane of Spores of Bacillus subtilis and Sensitizes Spores to Subsequent Stress. Journal of Applied Microbiology, 97, 838-852. https://doi.org/10.1111/j.1365-2672.2004.02370.x

[69] Saikia, D. and Sit, N. (2014) Effect of Using Sourdough and Frozen Dough for Preparation of Breads on Quality, Shelf Life and Staling. American Journal of Food Technology, 9, 223-230. https://doi.org/10.3923/ajft.2014.223.230

[70] Sadeghi, A.F., Shahidi, S.A., Mortazavi and Sadeghi, B. (2008) Evaluation of Sourdough Effect on Microbiological Shelf Life and Sensory Properties of Iranian Barbari Bread. Biotechnology, 7, 354-356. https://doi.org/10.3923/biotech.2008.354.356

[71] Dal Bello, F., Clarke, C.I., Ryan, L.A.M., Ulmer, H., Schober, T.J., et al. (2007) Improvement of the Quality and Shelf Life of Wheat Bread by Fermentation with the Antifungal Strain Lactobacillus plantarum FST 1.7. Journal of Cereal Science, 45, 309-318. https://doi.org/10.1016/j.jcs.2006.09.004

[72] Strom, K., Sjogren, J., Broberg, A. and Schnurer, J. (2002) Lactobacillus plantarum MiLAB 393 Produces the Antifungal Cyclic Dipeptides Cyclo(l-Phe-1-Pro) and Cyclo(l-Phe-trans-4-OH-1-Pro) and 3-Phenyllactic Acid. Applied Environmental Microbiology, 68, 4322-4327. https://doi.org/10.1128/AEM.68.9.4322-4327.2002

[73] Arena, M.P., Silvain, A., Normanno, G., Grieco, F., Drider, D., Spano, G. and Fiocco, D. (2016) Use of Lactobacillus plantarum Strains as a Bio-Control Strategy against Food-Borne Pathogenic Microorganisms. Frontiers in Microbiology, 7, 464. https://doi.org/10.3389/fmicb.2016.00464

[74] Katina, K., Msauri, H., Alakomi, H.L. and Mattila-Sandholm, T. (2002) Potential of Lactic Acid Bacteria to Inhibit Rope Spoilage in Wheat Sourdough Bread. LWT-Food Science and Technology, 35, 38-45. https://doi.org/10.1006/fstl.2001.0808

[75] Carlin, F. (2011) Origin of Bacterial Spores Contaminating Foods. Food Microbiology, 28, 177-182. https://doi.org/10.1016/j.fm.2010.07.008

[76] Hornstra, L.M., Ter Beek, A., Smelt, J.P., Kallemeijn, W.W. and Stanley, B. (2009) On the Origin of Heterogeneity in (Preservation) Resistance of Bacillus Spores: Input for a "Systems" Analysis Approach of Bacterial Spore Outgrowth. International Journal of Food Microbiology, 134, 9-15. https://doi.org/10.1016/j.ijfoodmicro.2009.02.011

[77] Andriani, Y., Safitri, R., Rochima, E. and Fakhrudin, S.D. (2017). Characterization of Bacillus subtilis and B. licheniformis Potentials as Probiotic Bacteria in Vanamei 
Shrimp Feed (Litopenaeus Vannamei Boone, 1931). Nusantara Bioscience, 9, 188-193. https://doi.org/10.13057/nusbiosci/n090214

[78] Røssland, E., Langsrud, T., Granum, P.E. and Sørhaug, T. (2005) Production of Antimicrobial Metabolites by Strains of Lactobacillus or Lactococcus Co-Cultured with Bacillus cereus in Milk. International Journal of Food Microbiology, 98, 193-200. https://doi.org/10.1016/j.ijfoodmicro.2004.06.003

[79] Immink, K.A.S. and Weber, J.H. (2010) Minimum Pearson Distance Detection for Multilevel Channels with Gain and/or Offset Mismatch. IEEE Transactions on Information Theory, 60, 5966-5974. https://doi.org/10.1109/TIT.2014.2342744

[80] Cetin-Karaca, H. and Newman, M.C. (2018) Antimicrobial Efficacy of Phytochemicals against Bacillus cereus in Reconstituted Infant Rice Cereal. Food Microbiology, 69, 189-195. https://doi.org/10.1016/j.fm.2017.08.011

[81] Guerin, A., Dargaignaratz, C., Broussolle, V., Clavel, T. and Nguyen-The, C. (2016) Combined Effect of Anaerobiosis, Low $\mathrm{pH}$ and Cold Temperatures on the Growth Capacities of Psychrotrophic Bacillus cereus. Food Microbiology, 59, 119-123. https://doi.org/10.1016/j.fm.2016.05.015

[82] Barbosa, J., Borges, S. and Teixeira, P. (2016) Effect of Different Conditions of Growth and Storage on the Cell Counts of Two Lactic Acid Bacteria after Spray Drying in Orange Juice. Beverages, 2, 8. https://doi.org/10.3390/beverages2020008

[83] Fan, H., Zhang, Z.W., Li, Y., Zhang, X., Duan, Y.M. and Wang, Q. (2017) Biocontrol of Bacterial Fruit Blotch by Bacillus subtilis 9407 via Surfactin-Mediated Antibacterial Activity and Colonization. Frontiers in Microbiology, 8, 1973.

https://doi.org/10.3389/fmicb.2017.01973

[84] Browne, N. and Dowds, B.C. (2002) Acid Stress in the Food Pathogen Bacillus cereus. Journal of Applied Microbiology, 92, 404-414. https://doi.org/10.1046/j.1365-2672.2002.01541.x

[85] Koni, T.N.I., Rusman, Hanim, C. and Zuprizal (2017) Effect of pH and Temperature on Bacillus subtilis FNCC 0059 Oxalate Decarboxylase Activity. Pakistan Journal of Biological, 20, 436-441. https://doi.org/10.3923/pjbs.2017.436.441

[86] Setlow, P. (2014) Spore Resistance Properties. Microbiology Spectrum, 2. https://doi.org/10.1128/microbiolspec.TBS-0003-2012 